DOI: http://doi.org/10.21698/simi.2018.fp24

\title{
CHARACTERIZATION OF MINERAL SPRINGS FROM THE BUILA- VANTURARITA NATURAL PARK AREA
}

\author{
Ovidiu Teodor Matica, Luisa Roxana Popescu
}

National Research and Development Institute for Industrial Ecology - ECOIND - Ramnicu Valcea Subsidiary, 1 Uzinei, 240050, Ramnicu Valcea, valcea@incdecoind.ro, Romania

\begin{abstract}
This study present the results of the physico-chemical, microbiological and hydrochemical characterization obtained for the mineral water samples taken from 14 mineral springs located in the Buila-Vinturarita National Park area.

For this study, has been conducted three sampling campaigns, in November 2017, March 2018 and June 2018, for each mineral spring.

The physico-chemical quality indicators analyzed for each source were: $\mathrm{pH}$, chlorides, sulfates, bicarbonates, sodium, potassium, calcium, magnesium, total silica and sulfides and hydrogen sulfide. In parallel with the physico-chemical indicators, microbiological indicators were also determined, namely: total number of bacteria at $22^{\circ} \mathrm{C}$, total number of bacteria at $37^{\circ} \mathrm{C}$, total coliform bacteria, Escherichia coli, enterococci and Pseudomona aeruginosa.

The results of the physico-chemical and microbiological analyzes obtained for the studied mineral springs were compared with the provisions of the Romanian legislation in force GD 1020/2005, which transposes into the national legislation the European Directive 2009/54 / EC.

Also in the present study, along with the physico-chemical and microbiological characterization of the mineral water samples, studies were carried out on the hydrochemical characterization of these springs.

These hydrochemical characterization studies were done by plotting the "Piper Diagrams". With the help of the Piper Diagrams, we could have a more detailed view of the mineral springs studied, from the analytical point of view and from the point of view of the typology of these springs.
\end{abstract}

Keywords: hydrochemical typology, mineral water, Piper diagram, spring water

\section{Introduction}

The chemical content of mineral waters depends mainly on the geological structure of the subsoil, especially its structure and lithology. The chemical composition of water provides important information on the operation of the hydromineral system. The classification of mineral water is very important for the assessment of its 


\section{INTERNATIONAL SYMPOSIUM "THE ENVIRONMENT AND THE INDUSTRY", SIMI 2018, PROCEEDINGS BOOK}

characteristics. Various classification systems have developed, sometimes to the point that, there are more authors of classification schemes than users (Eggenkamp et al 2013). One of the methods widely used in the assessment of surface and underground waters is the determination of hydrochemical typologies. This method is capable of providing sufficient information on the chemical quality of water, especially its origin. However, over the years, the methods have undergone substantial changes without changing too much the theory on which they are based.

The first attempt in this direction was made by Hill (Hill RA 1940), then it was modified by Piper (Piper AM 1944). Also, other authors (Sajil Kumar 2013, Teng et al 2016) used the Piper Diagram for various applications and bringing improvements. From the literature studies (Stanescu et al 2017, Catianis et al 2017, Dede et al 2017, Radulescu 2017, Angheluta \& Radulescu 2017), we can note to the interest of the researchers regarding the knowledge of the physicochemical and microbiological quality of the water as environmental factor. In the last years, from the large number of bibliographic sources (Valjarević et al 2018, Hichem, et al 2018, Zhao et al 2018), we can observe the interest of researchers and research institutes to have an overview of the water as environment factor.

The hydrogeochemical characterization of mineral water sources in different regions of the world, the presentation of how they were influenced by natural and artificial phenomena, shows the evolution of their quality over time. Due to its importance, mineral water sources have been characterized and classified by a number of authors around the world (Walraevens et al 2018, Zereg et al 2018). In Portugal (Eggenkamp et al 2013) and in Slovakia (Bodiš et al 2010) have carried out a classification of mineral waters using chemical analysis in the literature and the latest water quality monitoring analyzes. The Muğla (Avsar et al 2016) and Kozakli areas (Pasvanoğlu \& Chandrasekharam 2010) in Turkey and the Jingyu region of China (Zhang et al 2017) were hydrogeochemically described. In Romania, the area located between the Harghita Mountains and the Transylvanian Basin, well known for the abundance and diversity of the mineral water springs was characterized by the quantification of the chemical content and correlations between the structure geological subsoil and chemical composition of water (Kis et al 2012).

The first chemical studies on mineral waters in the Buila-Vanturarita Natural Park area were conducted in 1829-1830 by Dr. Karl Friedrich Siller (Dumitrescu 1978). In 1910, Dr. Ion Puturianu (Puturuianu 1910) grouped the mineral springs in several categories, after the chemical composition and after their action on the body. The complex studies carried out by various researchers on mineral waters, especially by M. Feru between 1969 and 1985 (Feru 1972, Feru 1978a, Feru 1978b) showed that the chemical elements (anions, cations) in these waters present variations (especially in the case of large precipitations or earthquakes), but not in large proportions, which demonstrates their chemical stability.

This study illustrates the results obtained by analyzing samples of mineral water taken from 14 mineral springs located in the Buila-Vinturarita National Park area. The obtained results were compared with the provisions of the Romanian legislation 


\section{INTERNATIONAL SYMPOSIUM "THE ENVIRONMENT AND THE INDUSTRY", SIMI 2018, PROCEEDINGS BOOK}

in force. At the same time, Piper Diagrams were also drawn to follow the hydrochemical evolution of the mineral waters studied.

\section{Materials and Methods}

All chemicals used to prepare reagent solutions, were analytical grade, according to the standards of dermination methods in use.

The equipment used to determine the quality indicators analyzed was: $\mathrm{pH}$ determined by multiparameter Thermo Scientific Orion Star A 215; sulfates and sulphides and hydrogen sulphide determined by a Spectrophotometer Analytic Jena UV-VIS-SPECORD 210 Plus; total silica determined by a Spectrophotometer UV-VIS-WTW PHOTO LAG S12; sodium and potassium determined by Flame photometer Analytic Jena FLAFO 4/766695. To determine the volumetric indicators (chloride, bicarbonate, calcium and magnesium) were used calibrated burette with volume $10 \mathrm{ml}, 25 \mathrm{ml}$ and $50 \mathrm{ml}$.

For the determination of microbiological parameters (total number of bacteria at $22^{\circ} \mathrm{C}$, total number of bacteria at $37^{\circ} \mathrm{C}$, total coliform bacteria, Escherichia coli, enterococci, Pseudomona aeruginosa) were used the following equipment: oven (incubator with cooling), Laboratory Binder Type FD115, Analytical Balance Mettler Toledo Type XS205DU / M, SYSTEC Autoclave Type VE 120, Series 2600, Vertical Autoclave Type 5050 ELV Series 2409682.

The quality indicators analyzed were determined using standardized methods, also the water samples were taken using standardized methods.

\section{Results and Discussion}

In this study, 14 samples were collected from springs located near the BuilaVinturarita (Figure 1). For each spring, three sampling campaigns were carried out in November 2017, March 2018 and June 2018.
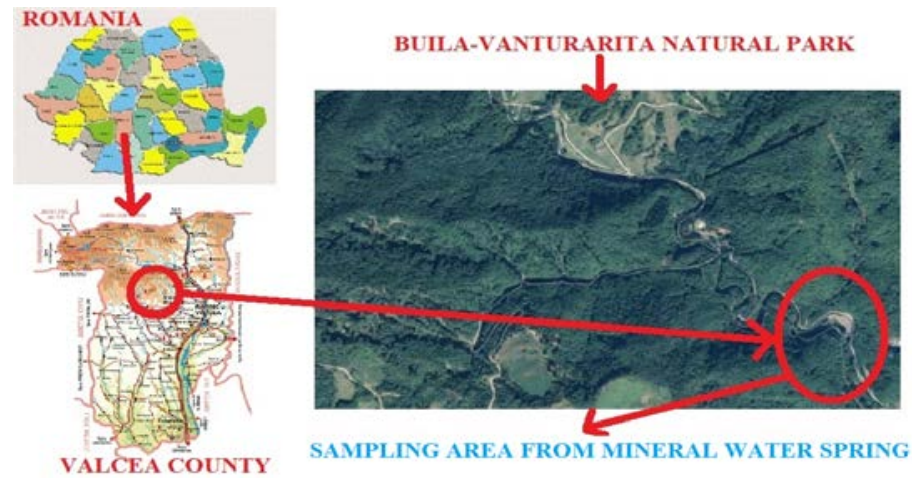

Figure 1. Location area for mineral water springs. 


\section{INTERNATIONAL SYMPOSIUM "THE ENVIRONMENT AND THE INDUSTRY", SIMI 2018, PROCEEDINGS BOOK}

The studied qualities were: $\mathrm{pH}$, chlorides, sulfates, bicarbonates, sodium, Potassium, calcium, magnesium, total silica, sulphides and hydrogen sulphide, total number of bacteria at $22^{\circ} \mathrm{C}$, total number of bacteria at $37^{\circ} \mathrm{C}$, total coliform bacteria, Escherichia coli, enterococci and Pseudomona aeruginosa.

The results obtained, after analyzing the quality indicators studied, were compared with the legislation in force.

For a better characterization of studied mineral waters, Piper Diagrams were drawn using Diagarammes (Laboratoire d'Hydrogéochimie d'Avignon, 2018). With these, the hydrochemical evolution of studied mineral waters was followed.

\section{Physico-chemical characterization of the springs studied}

The values of the physical-chemical quality indicators analyzed for the studied mineral waters are illustrated in Table 1. After comparison with the legislation in force was observed that these indicators are within the limits imposed by law, it was "according to the specific characteristics of mineral water analyzed".

Values of quality indicators physicochemical analysis does not vary uniformly for all sources studied.

The value of the bicarbonate quality indicator for the samples taken in June 2018 from all the studied springs reached the highest values. Similarly, for the quality indicator, total silica, higher values were observed for all mineral water samples taken in March and June 2018. These increases in indicator values, total silica and bicarbonate, can be explained by the accumulation of these indicators in spring water samples due to the discontinuous flow of springs during this period.

\section{Microbiological characterization of the springs studied}

Evolution of microbiological parameters for the studied springs can be seen in Table 1 and Figure 2.

In the water from all the studied springs, during the entire study period, the microbiological quality indicator Escherichia coli was not met.

The values determined for the microbiological quality indicators, enterococci, the total number of coliform bacteria and Pseudomonas aeruginosa, generally fall within the values allowed by the legislation in force, with the exception of samples taken in June 2018 from spring IZ 8 for the qualitative indicators enterococi and Pseudomonas aeruginosa and from spring IZ 9 for the quality indicator the total number of coliform bacteria.

For the microbiological quality indicators, the total number of bacteria at $22^{\circ} \mathrm{C}$ and the total number of bacteria at $37^{\circ} \mathrm{C}$, the values determined for the samples taken in November 2017 are generally in the values allowed by the legislation in force, but for the samples taken in March and June 2018 do not fall within the values allowed by the legislation in force (Table 1, Figure 2). During this period, when the values of the microbiological quality indicators exceeded the values allowed by the legislation in force, the springs had a discontinuous flow, which could have favored the development of microbiological bacteria. 


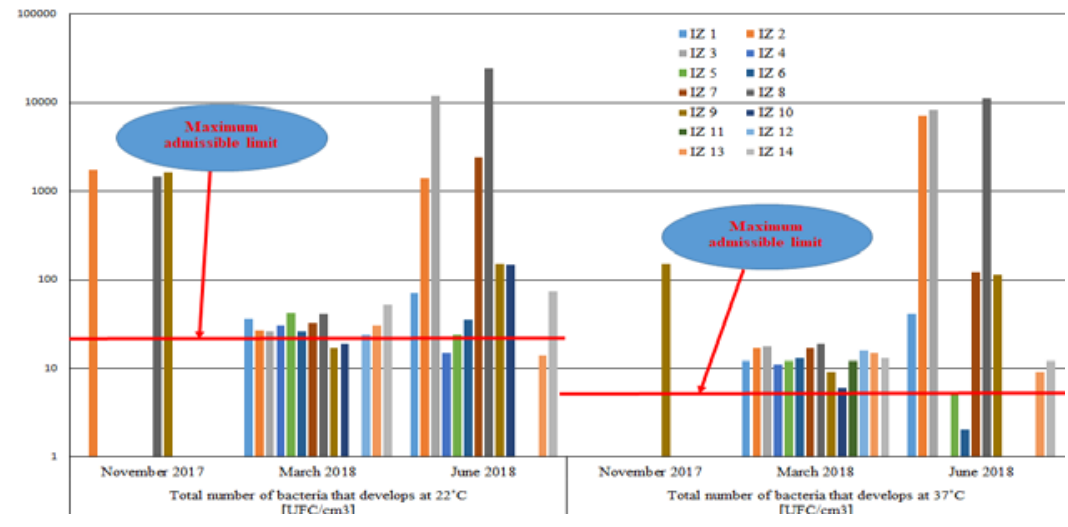

Figure 2. The evolution of microbiological quality indicators for the mineral springs studied.

\section{Hydrochemical characterization of mineral waters using Piper diagrams}

For better observation of the variation of hydrochemical parameters and classification of water sources studied were built Piper Diagrams for each set of samples of water taken (Figure 3). Generally, as can be seen from Figure 3 (A), (B) and (C), the hydrochemical typologies of the mineral springs studied do not change from one sampling campaign to the other. Exceptions are the waters of the springs IZ 2; IZ 7; IZ 9 and IZ 14.

In the case of mineral water from the spring IZ 2, the hydrochemical typologies change from alkaline earths, salts of strong acids, types of calcium chloride, calcium, chlorides in November 2017 and March 2018 to alkaline earths salts, weak acid salts, bicarbonate magnesium type, magnesium, bicarbonate in June 2018. It is noted the change of calcium-dominated cation in November 2017 and March 2018 to magnesium June 2018. The dominant anion changed from chloride in November 2017 to bicarbonate in June 2018.

In the case of the mineral waters from the spring IZ 7, their hydrochemical typology does not change to a very large extent, they change from chlorides as the dominant anion in November 2017 and March 2018 to a type of water in which we do not have a major anion in June 2018.

In the case of the mineral waters of the spring IZ9, they change the hydrochemical typology from alkaline waters, salts of strong acids, sodium chloride type, dominant sodium and potassium cations, no dominant anions in November and March 2018 to alkaline earths, weak acid salts, bicarbonate magnesium type, non-cationic dominant, bicarbonate salts in June 2018. 
Table 1. The results of physical-chemical and microbiological quality indicators analyzed, obtained for studied springs

\begin{tabular}{|c|c|c|c|c|c|c|c|c|c|}
\hline \multirow{2}{*}{$\begin{array}{c}\text { Parameter } \\
\text { determined }\end{array}$} & \multirow[t]{2}{*}{ U.M. } & \multirow{2}{*}{ Sample } & \multicolumn{7}{|c|}{ Parameter value determined } \\
\hline & & & IZ 1 & IZ 2 & IZ 3 & IZ 4 & IZ 5 & IZ 6 & IZ 7 \\
\hline \multirow{3}{*}{ pH } & & November & 7.7 & 7.6 & 8 & 7.6 & 8 & 8 & 7.9 \\
\hline & Unit pH & March 2018 & 8 & 7.9 & 7.9 & 7.6 & 8.4 & 7.9 & 8 \\
\hline & & June 2018 & 7.8 & 7.6 & 8.2 & 7.8 & 8 & 8 & 8.1 \\
\hline \multirow{3}{*}{ Chloride } & & November 2017 & 5531 & 425 & 3120 & 4113 & 2553 & 2694 & 319 \\
\hline & $\mathrm{mg} / \mathrm{L}$ & March 2018 & 5928 & 236 & 2964 & 4042 & 2290 & 2425 & 269 \\
\hline & & June 2018 & 5793 & 7 & 3200 & 3772 & 2223 & 2290 & 283 \\
\hline \multirow{3}{*}{ Sulfates } & & November 2017 & 4 & 158 & 7 & 2 & 7 & 1 & 114 \\
\hline & $\mathrm{mg} / \mathrm{L}$ & March 2018 & 5 & 158 & 25 & 2 & 4 & 4 & 78 \\
\hline & & June 2018 & 7 & 144 & 26 & 4 & 21 & 2 & 70 \\
\hline \multirow{3}{*}{ Bicarbonate } & & November 2017 & 244 & 403 & 293 & 281 & 378 & 329 & 342 \\
\hline & $\mathrm{mg} / \mathrm{L}$ & March 2018 & 281 & 354 & 305 & 256 & 293 & 354 & 317 \\
\hline & & June 2018 & 329 & 525 & 464 & 415 & 500 & 512 & 537 \\
\hline \multirow{3}{*}{ Sodium } & & November 2017 & 2589 & 7 & 1737 & 1416 & 1324 & 1324 & 236 \\
\hline & $\mathrm{mg} / \mathrm{L}$ & March 2018 & 3107 & 9 & 1829 & 2391 & 3769 & 3769 & 217 \\
\hline & & June 2018 & 2004 & 5 & 1921 & 2391 & 3750 & 2600 & 180 \\
\hline \multirow{3}{*}{ Potassium } & & November 2017 & 86 & 8 & 43 & 46 & 32 & 31 & 9 \\
\hline & $\mathrm{mg} / \mathrm{L}$ & March 2018 & 81 & 9 & 44 & 74 & 32 & 33 & 11 \\
\hline & & June 2018 & 81 & 7 & 41 & 43 & 28 & 31 & 9 \\
\hline \multirow{3}{*}{ Calcium } & & November 2017 & 262 & 160 & 160 & 180 & 84 & 204 & 88 \\
\hline & $\mathrm{mg} / \mathrm{L}$ & March 2018 & 281 & 104 & 136 & 180 & 80 & 79 & 58 \\
\hline & & June 2018 & 281 & 88 & 140 & 172 & 92 & 82 & 59 \\
\hline \multirow{3}{*}{ Magnesium } & & November 2017 & 141 & 10 & 41 & 71 & 51 & 39 & 63 \\
\hline & $\mathrm{mg} / \mathrm{L}$ & March 2018 & 122 & 58 & 73 & 68 & 49 & 35 & 32 \\
\hline & & June 2018 & 119 & 109 & 66 & 73 & 41 & 40 & 31 \\
\hline \multirow{3}{*}{ Total silica } & & November 2017 & 3 & 2 & 2 & 3 & 2 & 2 & 2 \\
\hline & $\mathrm{mg} / \mathrm{L}$ & March 2018 & 17 & 16 & 17 & 16 & 16 & 16 & 15 \\
\hline & & June 2018 & 15 & 14 & 15 & 14 & 14 & 14 & 13 \\
\hline \multirow{3}{*}{$\begin{array}{l}\text { Sulphides and } \\
\text { hydrogen sulphide }\end{array}$} & & November 2017 & 120 & 0.1 & 15 & 102 & 76 & 106 & 67 \\
\hline & $\mathrm{mg} / \mathrm{L}$ & March 2018 & 158 & 0.1 & 74 & 116 & 109 & 108 & 66 \\
\hline & & June 2018 & 155 & 0.1 & 33 & 112 & 106 & 129 & 70 \\
\hline \multirow{3}{*}{ Escherichia coli } & UFC/ & November 2017 & 0 & 0 & 0 & 0 & 0 & 0 & 0 \\
\hline & $100 \mathrm{~cm}^{3}$ & March 2018 & 0 & 0 & 0 & 0 & 0 & 0 & 0 \\
\hline & & June 2018 & 0 & 0 & 0 & 0 & 0 & 0 & 0 \\
\hline \multirow{3}{*}{ Enterococi } & & November 2017 & 0 & 0 & 0 & 0 & 0 & 0 & 0 \\
\hline & UFC/ & March 2018 & 0 & 0 & 0 & 0 & 0 & 0 & 0 \\
\hline & & June 2018 & 0 & 0 & 0 & 0 & 0 & 0 & 0 \\
\hline \multirow{3}{*}{$\begin{array}{l}\text { Total number of } \\
\text { bacteria at } 22^{\circ} \mathrm{C}\end{array}$} & UFC/ & November 2017 & 0 & 1764 & 0 & 0 & 0 & 0 & 1 \\
\hline & $\mathrm{cm}^{3}$ & March 2018 & 36 & 27 & 26 & 31 & 42 & 26 & 32 \\
\hline & & June 2018 & 72 & 1382 & 12200 & 15 & 24 & 35 & 2427 \\
\hline \multirow{3}{*}{$\begin{array}{l}\text { Total number of } \\
\text { bacteria at } 37^{\circ} \mathrm{C}\end{array}$} & & November 2017 & 0 & 0 & 0 & 0 & 0 & 0 & 0 \\
\hline & $\mathrm{cm}^{3}$ & March 2018 & 12 & 17 & 18 & 11 & 12 & 13 & 17 \\
\hline & & June 2018 & 41 & 7200 & 8400 & 0 & 5 & 2 & 123 \\
\hline \multirow{3}{*}{$\begin{array}{l}\text { Total coliform } \\
\text { bacteria }\end{array}$} & & November 2017 & 0 & 0 & 0 & 0 & 0 & 0 & 0 \\
\hline & $100 \mathrm{~cm}^{3}$ & March 2018 & 0 & 0 & 0 & 0 & 0 & 0 & 0 \\
\hline & & June 2018 & 0 & 0 & 0 & 0 & 0 & 0 & 0 \\
\hline & UFC/ & November 2017 & 0 & 0 & 0 & 0 & 0 & 0 & 0 \\
\hline aeruginosa & $100 \mathrm{~cm}^{3}$ & March 2018 & 0 & 0 & 0 & 0 & 0 & 0 & 0 \\
\hline & & June & 0 & 0 & 0 & 0 & 0 & 0 & 0 \\
\hline
\end{tabular}




\begin{tabular}{|c|c|c|c|c|c|c|c|c|c|}
\hline \multirow{2}{*}{$\begin{array}{c}\text { Parameter } \\
\text { determined }\end{array}$} & \multirow[t]{2}{*}{ U.M. } & \multirow{2}{*}{ Sample } & \multicolumn{7}{|c|}{ Parameter value determined } \\
\hline & & & IZ 8 & IZ 9 & IZ 10 & IZ 11 & IZ 12 & IZ 13 & IZ 14 \\
\hline \multirow{3}{*}{$\mathbf{p H}$} & \multirow{3}{*}{ Unit $\mathrm{pH}$} & November & 7.7 & 7.7 & 8.4 & 8.2 & 7.7 & 7.8 & 8 \\
\hline & & March 2018 & 7.8 & 7.9 & 8.4 & 8.4 & 8 & 7.8 & 8.1 \\
\hline & & June 2018 & 7.8 & 7.8 & 8.3 & 8.5 & 7.5 & 7.7 & 8.3 \\
\hline \multirow{3}{*}{ Chloride } & \multirow{3}{*}{$\mathrm{mg} / \mathrm{L}$} & November & 155 & 175 & 2 & 922 & 3971 & 2836 & 45 \\
\hline & & March 2018 & 147 & 182 & 20 & 916 & 4581 & 3099 & 47 \\
\hline & & June 2018 & 122 & 128 & 23 & 943 & 3974 & 2829 & 58 \\
\hline \multirow{3}{*}{ Sulfates } & \multirow{3}{*}{$\mathrm{mg} / \mathrm{L}$} & November & 155 & 175 & 2 & 26 & 19 & 21 & 87 \\
\hline & & March 2018 & 147 & 182 & 20 & 7 & 3 & 6 & 107 \\
\hline & & June 2018 & 122 & 128 & 23 & 12 & 4 & 26 & 137 \\
\hline \multirow{3}{*}{ Bicarbonate } & \multirow{3}{*}{$\mathrm{mg} / \mathrm{L}$} & November & 305 & 342 & 293 & 427 & 268 & 427 & 325 \\
\hline & & March 2018 & 232 & 305 & 281 & 281 & 293 & 439 & 305 \\
\hline & & June 2018 & 500 & 464 & 512 & 525 & 378 & 622 & 427 \\
\hline \multirow{3}{*}{ Sodium } & \multirow{3}{*}{$\mathrm{mg} / \mathrm{L}$} & November & 70 & 162 & 674 & 713 & 2485 & 1913 & 125 \\
\hline & & March 2018 & 81 & 144 & 695 & 787 & 2505 & 1913 & 90 \\
\hline & & June 2018 & 67 & 89 & 530 & 28 & 4000 & 3600 & 109 \\
\hline \multirow{3}{*}{ Potassium } & \multirow{3}{*}{$\mathrm{mg} / \mathrm{L}$} & November & 7 & 7 & 13 & 13 & 46 & 46 & 6 \\
\hline & & March 2018 & 7 & 9 & 14 & 13 & 68 & 44 & 6 \\
\hline & & June 2018 & 7 & 6 & 11 & 10 & 45 & 46 & 5 \\
\hline \multirow{3}{*}{ Calcium } & \multirow{3}{*}{$\mathrm{mg} / \mathrm{L}$} & November & 56 & 68 & 28 & 24 & 180 & 128 & 56 \\
\hline & & March 2018 & 53 & 72 & 16 & 14 & 168 & 116 & 40 \\
\hline & & June 2018 & 56 & 69 & 21 & 22 & 184 & 124 & 43 \\
\hline \multirow{3}{*}{ Magnesium } & & November & 51 & 46 & 15 & 12 & 75 & 73 & 53 \\
\hline & $\mathrm{mg} / \mathrm{L}$ & March 2018 & 36 & 29 & 10 & 10 & 80 & 44 & 44 \\
\hline & & June 2018 & 40 & 31 & 11 & 6 & 68 & 70 & 9 \\
\hline & & November & 1 & 1 & 2 & 1 & 4 & 3 & 3 \\
\hline Total silica & $\mathrm{mg} / \mathrm{L}$ & March 2018 & 15 & 15 & 14 & 14 & 14 & 18 & 16 \\
\hline & & June 2018 & 13 & 14 & 14 & 14 & 15 & 18 & 16 \\
\hline & & November & $<0.01$ & $<0.01$ & 149 & 108 & 85 & 422 & 3 \\
\hline Supmes dida & $\mathrm{mg} / \mathrm{L}$ & March 2018 & 0.1 & 0.1 & 158 & 119 & 99 & 390 & 22 \\
\hline & & June 2018 & 0.1 & 0.1 & 188 & 153 & 120 & 459 & 21 \\
\hline & & November & 0 & 0 & 0 & 0 & 0 & 0 & 0 \\
\hline Escherichia coli & UFC/ & March 2018 & 0 & 0 & 0 & 0 & 0 & 0 & 0 \\
\hline & & June 2018 & 0 & 0 & 0 & 0 & 0 & 0 & 0 \\
\hline & & November & 0 & 0 & 0 & 0 & 0 & 0 & 0 \\
\hline Enterococi & $100 \mathrm{~cm}^{3}$ & March 2018 & 0 & 0 & 0 & 0 & 0 & 0 & 0 \\
\hline & & June 2018 & 20 & 0 & 0 & 0 & 0 & 0 & 0 \\
\hline Total number of & UFC/ & November & 1473 & 1627 & 0 & 0 & 0 & 0 & 0 \\
\hline bacteria at $22^{\circ} \mathrm{C}$ & $\mathrm{Cm}^{3}$ & March 2018 & 41 & 17 & 19 & 0 & 24 & 31 & 52 \\
\hline & & June 2018 & 24600 & 152 & 146 & 0 & 0 & 14 & 75 \\
\hline & & November & 0 & 150 & 0 & 0 & 0 & 0 & 0 \\
\hline I otal number or & UFU/ & March 2018 & 19 & 9 & 6 & 12 & 16 & 15 & 13 \\
\hline & & June 2018 & 11300 & 115 & 0 & 0 & 0 & 9 & 12 \\
\hline Total coliform & UFC/ & November & 0 & 0 & 0 & 0 & 0 & 0 & 0 \\
\hline bacteria & $100 \mathrm{~cm}^{3}$ & March 2018 & 0 & 0 & 0 & 0 & 0 & 0 & 0 \\
\hline & & June 2018 & 0 & 73 & 0 & 0 & 0 & 0 & 0 \\
\hline & & November & 0 & 0 & 0 & 0 & 0 & 0 & 0 \\
\hline geruaingsa & $\begin{array}{c}\text { UFC/ } \\
100 \mathrm{~cm}^{3}\end{array}$ & March 2018 & 0 & 0 & 0 & 0 & 0 & 0 & 0 \\
\hline & & June 2018 & 44 & 0 & 0 & 0 & 0 & 0 & 0 \\
\hline
\end{tabular}




\section{INTERNATIONAL SYMPOSIUM "THE ENVIRONMENT AND THE INDUSTRY", SIMI 2018, PROCEEDINGS BOOK}

In the case of mineral water from spring IZ 14, it changes its hydrochemical typology, from alkaline-earth, weak acid salts, bicarbonate magnesium type, noncationic dominant, bicarbonate in November 2017 and March 2018 to in alkaline waters, salts of weak acids, mixed type, sodium and potassium dominant cationic, bicarbonate in June 2018.

The modification of the hydrochemical typologies of the water sources of the springs IZ 2, IZ 7, IZ 9 and IZ 14 lead us to the conclusion that they are influenced by external factors (precipitation, drought, water infiltration, etc.).

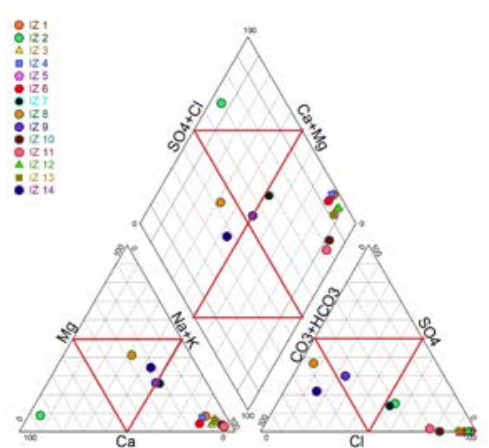

(A)

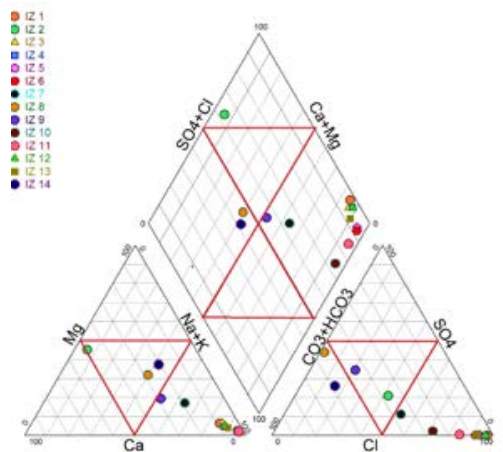

(B)

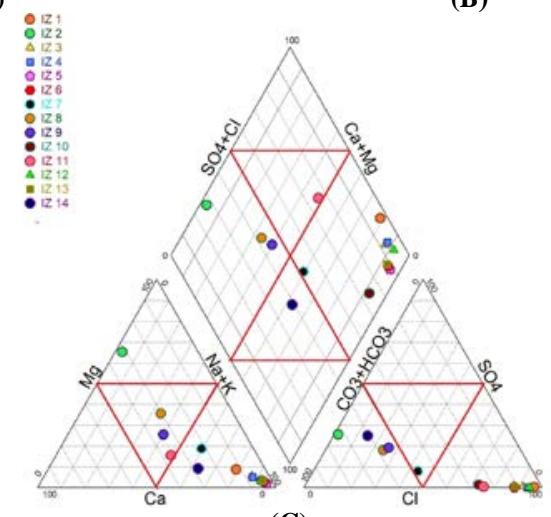

(C)

Figure 3. Piper diagrams for all springs studied in the three sampling campaigns: A - samples taken in November 2017, B - samples taken in March 2018 and C - samples taken in June 2018. 


\section{INTERNATIONAL SYMPOSIUM "THE ENVIRONMENT AND THE INDUSTRY", SIMI 2018, PROCEEDINGS BOOK}

\section{Conclusions}

The results of the physical and chemical analyzes obtained for the studied mineral springs, by comparison with the legislation in force, show that the physico-chemical parameters analyzed fall within the limits imposed by the law, being "in accordance with the specific characteristics of the analyzed mineral waters".

From the microbiological point of view, the results obtained for all springs studied in the three sampling campaigns, the following aspects can be observed: the analyzed quality indicators, total coliform bacteria, Escherichia coli, enterococci and Pseudomona aeruginosa, compared to the legislation in force, fall generally within the limits provided by the legislation; unlike the quality indicators, the total number of bacteria at $22^{\circ} \mathrm{C}$ and the total number of bacteria at $37^{\circ} \mathrm{C}$, which generally do not fall within the limits provided by the legislation in force.

The cause of the development of microbiological bacteria may be the discontinuous flow of springs, in the period when in the water from these springs were recorded exceedances of the microbiological parameters studied.

By drawing the Piper Diagrams, for all springs studied in the three sampling campaigns, it is observed that most of the studied mineral springs fall into types of alkaline mineral waters, hard acid salts, sodium chloride type, sodium and potassium cations, anions mostly chlorine. Also, using these diagrams we can see that in general the mineral springs studied keep their hydrochemical typology, except for four springs.

\section{Acknowledgements}

The authors are grateful for the financial support from National Research and Development Institute for Industrial Ecology Bucharest, where all the experimental studies were done.

\section{References}

Angheluta, PS \& Radulescu, CV 2017, 'Water resources in the context of globalization', 20 $0^{\text {th }}$ International Symposium “The environment and The industry”, SIMI 2017, National Research and Development Institute for Industrial Ecology ECOIND, Bucharest, pp. 330-337.

Avsar, Ö, Kurtuluş, B, Gürsu, S, Gençaliolu Kucu, G \& Kaçaroğlu, F 2016, 'Geochemical and isotopic characteristics of structurally controlled geothermal and mineral waters of Muğla (SW Turkey)', Geothermics, vol. 64, pp. 466-481.

Bodiš, D, Kordik, J, Slaninka, I, Malík, P, Liščák, P, Panák, D, Božíková J \& Marcin, D 2010, 'Mineral waters in Slovakia - Evaluation of chemical composition stability using both historical records and the most recent data', Journal of Geochemical Exploration, vol. 107, pp. 382-390.

Catianis, I, Secrieru, D, Scrieciu, D, Grosu, D, Pojar, I \& Pavel, AB 2017, 'Assessment of water and sediment characteristics of the northern Danube Delta lakes - Matița, Babina and Merhei, Romania', 20 ${ }^{\text {th }}$ International 


\section{INTERNATIONAL SYMPOSIUM "THE ENVIRONMENT AND THE INDUSTRY", SIMI 2018, PROCEEDINGS BOOK}

Symposium “The environment and The industry”, SIMI 2017, National Research and Development Institute for Industrial Ecology ECOIND, Bucharest, pp. 134-141.

Catrina, SC \& Catrina V 1992, 'Baile Olanesti', Abeona Publishing House, Bucharest.

Chelnokov, G, Kharitonova, N, Bragin, I \& Chudaev, O 2015, 'Geochemistry of mineral water and gases of the Razdolnoe Spa (Primorye, Far East of Russia)', Applied Geochemistry, vol. 59, pp. 147-154.

Dede, OT, Misır, FY \& Telci, İT 2017, 'The using of principal component analysis for the assessment of water quality in Kirmir basin', $20^{\text {th }}$ International Symposium "The environment and The industry", SIMI 2017, National Research and Development Institute for Industrial Ecology ECOIND, Bucharest, pp. 197-204.

Dumitrescu, C 1978, 'Hydrogeological studies and hydro-mineral reserves in Baile Olanesti resort, Valcea County’, Archives I.M.F.B.R.M, Bucharest, vol. I.

Eggenkamp HGM \& Marque, JM 2013, 'A comparison of mineral water classification techniques: Occurrence and distribution of different water types in Portugal (including Madeira and the Azores)', Journal of Geochemical Exploration, vol. 132, pp. 125-139.

Feru, M 1972, 'Genesis of the Olanesti mineral water', Institute of Romanian Geology, Technical and Economic Studies, E series, no. 10.

Feru, M 1978, 'Report on hydrogeological studies to determine the evolution of hydrogeological parameters of mineral water sources in the resort area Olanesti, Valcea County،, Archives I.G.P.S.M.S., Bucharest.

Feru, M 1978, 'Mineral water from Olanesti', Institute of Romanian Geology, Economic Studies, E series, no. 13.

GD 1020 2005, Government Decision no. 1020 for the approval of the Technical Norms for the exploitation and marketing of natural mineral waters, Romanian Official Monitor no. 854 from 22th September, 2005.

Hichem, C, Belgacem, H \& Valles, V 2018, 'Hydrogeochemistry and geothermometry of thermal water from northeastern Algeria', Geothermics vol. 75, pp. 137-145.

Hill RA 1940, 'Geochemical patterns in the Coachella valley, California', Eos, Transactions American Geophysical Union, vol. 21, pp. 46-49.

Kis BM, Czellecz, B, Baciu, C \& Kékedy-Nagy, L 2011, 'Hydrogeochemical features of some mineral waters at the contact between Harghita Mts. (Eastern Carpathians) and the Transylvanian Basin', Landscape, Environment, European Identity, 4-6 November, 2011, Bucharest, Procedia Environmental Sciences, vol. 14 , pp. $195-206$.

Laboratoire d'Hydrogéochimie UFR-ip Sciences, Technologie, Santé, 2018, 'DIAGRAMMES: Logiciel d'hydrochimie- Water Software Quality Hydrochemistry diagrams', Available from : http://www.lha.univ-avignon.fr/.

Pasvanoğlu, S \& Chandrasekharam, D 2011, 'Hydrogeochemical and isotopic study of thermal and mineralized waters from the Nevşehir (Kozakli) area, Central 


\section{INTERNATIONAL SYMPOSIUM "THE ENVIRONMENT AND THE INDUSTRY", SIMI 2018, PROCEEDINGS BOOK}

Turkey', Journal of Volcanology and Geothermal Research, vol. 202, pp. 241-250.

Piper, AM 1944, 'A graphic procedure in geochemical interpretation of water analyses', Eos, Transactions American Geophysical Union, vol. 25, pp. 914923

Puturuianu, I 1910, 'Efectele fiziologice si proprietatile terapeutice ale apelor din statiunea Olanesti', Craiova. In Romanian.

Radulescu, V 2017, 'Control of inorganic and organic contamination, assessment of water quality in hydropower lakes on Jiu River', $20^{\text {th }}$ International Symposium "The environment and The industry", SIMI 2017, National Research and Development Institute for Industrial Ecology ECOIND, Bucharest, pp. 221228.

Sajil Kumar, PJ 2013,'Interpretation of groundwater chemistry using piper and chadha's diagrams: a comparative study from perambalur taluk', Elixir Geoscience, vol. 54, pp. 12208-12211.

Stanescu, B, Kim, K, Lehr C \& Stanescu, E 2017, 'Assessment of the environmental aspects in a city area affected by historical pollution', $20^{\text {th }}$ International Symposium "The environment and The industry", SIMI 2017, National Research and Development Institute for Industrial Ecology ECOIND, Bucharest, pp. 128-133.

Teng, WC, Fong, KL, Shenkar, D, Wilson, JA \& Foo, DCY 2016, 'Piper diagram. A novel visualisation tool for process design', Chemical Engineering Research and Design, vol. 112, pp. 132-145.

Valjarević, A, Srećković-Batoćanin, D, Valjarević, D \& Matović V 2018, ‘A GISbased method for analysis of a better utilization of thermal-mineral springs in the municipality of Kursumlija (Serbia)', Renewable and Sustainable Energy Reviews vol. 92, pp. 948-957.

Zhang, Q, Liang, X \& Xiao, C 2017, 'The hydrogeochemical characteristic of mineral water associated with water-rock interaction in Jingyu County, China', 15th Water-Rock Interaction International Symposium, WRI-15, Procedia Earth and Planetary Science, vol.17, pp. 726 - 729.

Zhao, G, Li, W, Li, F, Zhang,F \& Liu,G 2018, 'Hydrochemistry of waters in snowpacks, lakes and streams of Mt. Dagu, eastern of Tibet Plateau', Science of the Total Environment, vol. 610-611, pp. 641-650. 